\title{
On The Interpretability of Neural Networks and Dreams from an Observer's Perspective
}

Muhammad $\mathrm{Ali}^{1}$

${ }^{1}$ Affiliation: J\&N Research Labs

January 24, 2022

\section{Hosted file}

Manuscript.pdf available at https://authorea.com/users/456867/articles/553819-on-theinterpretability-of-neural-networks-and-dreams-from-an-observer-s-perspective 